\title{
JUDGMENT ON THE INFLUENCE OF THE CYLINDER ARM LENGTH AND STEERING WHEEL ANGLES ON THE MODIFIED TRACTOR HYDRAULICALLY
}

\author{
Ismail, Z. E.* and I. El-Sebaee**
}

\begin{abstract}
The aim of this investigation was to choose and develop the local hydraulic steering system. The components of modified system were the pump, steering unit, steering shaft, cylinder, double-shear clevis ends for the cylinder and rod ends. To evaluate the hydraulic steering system, the field experiment factors were three tractor forward speeds (4.0; 5.5 and $7.0 \mathrm{~km} / \mathrm{h}$ ) and four distance between the front wheel (77.5; 94.0; 109.5 and $125.5 \mathrm{~cm}$ ) that realized four " $l / b$ " ratios were identified to measure the steering angles, cylinder length and steering wheel parameters and its affecting field efficiency, turning time and tractor fuel consumption. A response surface methodology (RSM) is used to collect of mathematical and statistical techniques for empirical model building for steering of hydraulic tractor. Increasing the cylinder length $\left(L_{e f}\right)$ directly increases each of actual and theoretical outer steering angles $\left(\theta_{t h}{ }^{\circ}\right)$ at different ratio of $(l / b)$ and vice versa at increasing the $(l / b)$ ratio. The same relation was found for response of steering wheel. Practically, in the case of stability the average of turning radius for the hydraulic steering system was permanent as $2.5 \mathrm{~m}$ against $3.0 \mathrm{~m}$ for mechanical steering. The hydraulic steering system reduces the tractor turning radius, total fuel consumption, the time losses in the turning, and increasing the field efficiency.
\end{abstract}

\section{INTRODUCTION}

7 ractor is not much use if it cannot be steered or guided. The act of guiding is called steering. The tractor tires must meet the road at L the correct steering angle to get good traction and to prevent unnecessary tire wear. Habibi et al., (2008) used the engineering algorithm method to optimize the roll steer of a front McPherson suspension system.

\footnotetext{
* Prof. of Power Technology and Farm Machinery of Agric., Mansoura Univ. ** Ass. Res. in Agric. Eng. Res. Inst. (AEnRI), Giza.
} 
Real steering mechanisms are complex for spatial linkage geometry must be correlated with that of the linkages, because their kingpins are not parallel. They added that, steering suspension mechanism so as to minimize the cross-coupling effect between the steering and suspension. Also, Hanzaki et al., (2009) presented the sensitivity analysis of rackand-pinion steering linkage to predict how the steering error is affected by manufacturing tolerances, assembly errors, and clearances resulting from wear. While, Hoyle (2007) investigated a truck with leaf-spring suspension configuration for steering bump.

The beam axle will normally be attached to the mid-point of these leaves, and will inevitably move forwards and backwards as the axle moves up and down.

Watanabe et al., (2007) introduced a mathematical model for multi-axle vehicles in terms of turning characteristics and maneuverability performance. Their results indicate that rear steering has a great effect on the turning characteristics while the position of the steering center has little effect on the turning radius. In the same objective, El- Awady et al. (2009) indicated that actual and theoretical outer front wheels steering angles increases with increasing inner steering angles and also, the outer front wheels steering angles proportional with the hydraulic cylinder length. The perfect inner and outer steering angles decreased with increasing values of tractor dimension ratio. A decision support system was developed in visual basic 6.0 programming language for matching tillage implements with $2 \mathrm{WD}$ tractors and for predicting the field performance of the tractor-implement system (Sahu and Raheman2008). But, Xue-Ping et al. (2009) design the steering characteristic curve and they also evaluate proposes a power sinusoidal steering curve and study the detecting process of steering torque sensor in EPS control systems. A vision sensing system for the measurement of auto-guidance pass-to-pass and long-term errors was implemented to test steering performance of tractors equipped with auto-guidance systems, Dwight et al., (2010). Also, Michihisa et al. (2011) the turning performance of an articulated vehicle in which applying direct yaw-moment control is applied to reduce the turning radius. In the proposed method, a braking force is applied to inner tires when articulation angle reaches its 
maximum in turning, which generates a yaw-moment around the vehicle's centre of gravity.

As an important subject in the statistical design of experiments, the Response Surface Methodology (RSM) is a collection of mathematical and statistical techniques useful for the modeling and analysis of problems in which a response of interest is influenced by several variables and the objective is to optimize this response (Montgomery, 2005). While, the response surface was designed by Cheng and Bradley (2007) to fit response surface for designing, formulating, developing, and analyzing new scientific studying and products (Ismail et al. -2012). The aim of this paper is to choose and design the local hydraulic steering system for farm tractor.

\section{MATERIALS AND METHODS}

The IMT tractor of $26.1 \mathrm{~kW}$, air cooling with mechanical steering, 3cyliders, 2WD, diesel engine, $540 \mathrm{rpm}$, 6 forward speed and 2 reverse motions with 3 meter turn radius, was used as the base to carry out and construct the hydraulic steering system.

During turns, linkage wheels are slightly different. The re-circulating-ball steering gear contains a worm gear. The steering wheel connects to a threaded rod, similar to a bolt that sticks into the hole in the block. When the steering wheel turns, it turns the bolt. Instead of twisting further into the block the way a regular bolt would, this bolt is held fixed so that when it spins, it moves the block, which moves the gear that turns the wheels (figure-1). Instead of the bolt directly engaging the threads in the block, all of threads are filled with ball bearings that re-circulate through the gear.

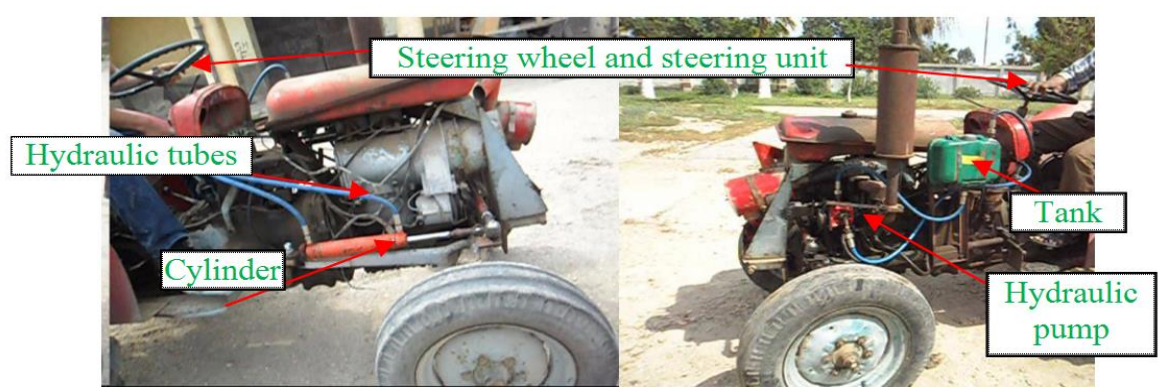

Figure (1): Tractor modifies from mechanical to hydraulic steering 


\section{Experimental variables}

The lab experimental variables were identified to measure the steering angles, cylinder length, steering wheel parameters performances under four front wheels distance of $77.5 ; 94.0 ; 109.5$ and $125.5 \mathrm{~cm}$ that achieves $(1 / \mathrm{p})$ ratio of $0.43 ; 0.52 ; 0.60$ and 0.7 . Although, the field experiments were identified on the traditional and modified tractor that connected with rotary cultivator. The rotary cultivator hanged on three point linkage system. Its mass of $230 \mathrm{~kg}$ with effective depth and width of 5.0 and $86.3 \mathrm{~cm}$ respectively. The power is provided to cultivator through tractor PTO. The experimental field was carry out at field planted with figs trees per unit tree area of $\left(5.0 \times 5.0 \mathrm{~m}^{2}\right)$. The field length and width were $100 \mathrm{~m}$ and $42 \mathrm{~m}$ respectively. The field area plotted as 8 lines and 20 rows with average free space between the trees of $2.0 \mathrm{~m}$. The total turning numbers were 30 times. Three tractor speeds $\left(\mathrm{V}_{1}=4.0 ; \mathrm{V}_{2}=5.5\right.$ and $\left.\mathrm{V}_{3}=7.0 \mathrm{~km} / \mathrm{h}\right)$ were used to calculate the tractor efficiency, turning time and fuel consumption.

To measure the steering wheel angles the protractor and pointer were used (figure-2). It was fixed under the front steering wheel and connected to the pointer. The stainless-steel meter was used as shown in figures ( 3 and 4) to measure the cylinder length .The meter was fixed on the top of the cylinder and connected to the end rod. The distance of the cylinder length was measured relative to the steering wheel rotated.

Fuel consumption of engines is measured in liters per second. The simple method is often used for measurement of total fuel consumption. The tank is filled to fuel capacity before and after the test. Amount of refueling after the test is the fuel consumption for the test when filling up the tank. Careful attention should be paid to keep the tank horizontal and not to leave empty space in the tank if this instruction is not observed the data on the fuel consumption would have serious errors.

\section{RESULTS AND DISCUSSIONS}

\section{Cylinder length via actual and theoretical steering angles}

The effect of the cylinder length $\left(\mathrm{L}_{\mathrm{ef}}\right)$ on each of the actual outer steering angles $\left(\theta_{\mathrm{ac}}{ }^{\circ}\right)$ and theoretical $\left(\theta_{\mathrm{th}}{ }^{\circ}\right)$ were illustrated in figures (5) and (6) at different ratio of $(1 / b)$. Generally, increasing the cylinder length $\left(\mathrm{L}_{\mathrm{ef}}\right)$ directly increases the actual outer steering angles at all different ratio of $(1 / b)$. On the other side, the $(1 / b)$ ratio was effective on $\left(\theta_{\mathrm{ac}}{ }^{\circ}\right)$. For example, 
at the cylinder length $\left(\mathrm{L}_{\mathrm{ef}}\right) 4.6 \mathrm{~cm}$ the $\left(\theta_{\mathrm{ac}}{ }^{\circ}\right)$ recorded $20.4^{\mathrm{o}} ; 19.3^{\circ} ; 18.4^{\circ}$ and $17.3^{\circ}$ for $(1 / b) 0.43 ; 0.52 ; 0.60$ and 0.7 respectively.

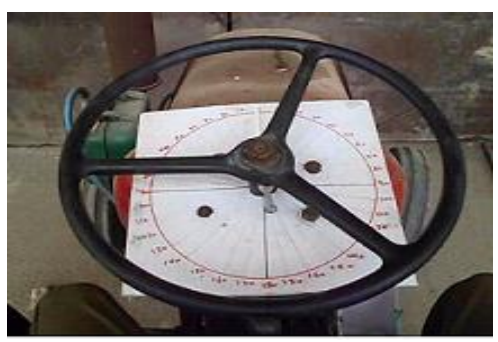

Figure (2): Measuring the steering wheel angles
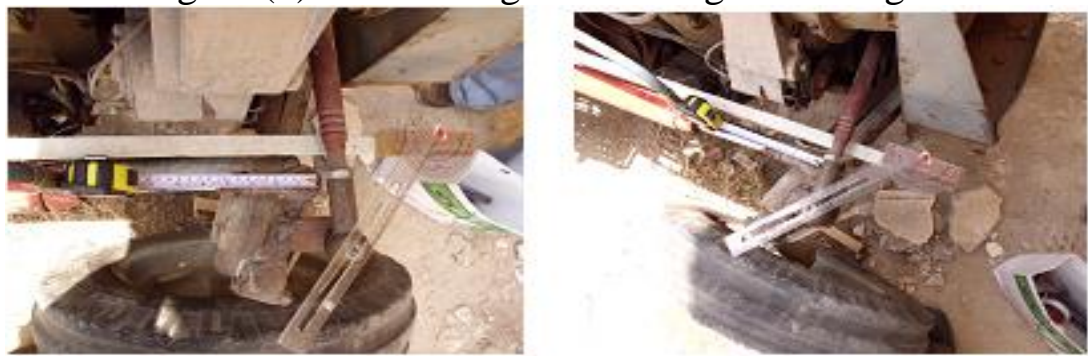

Figure (3): The cylinder length measurements

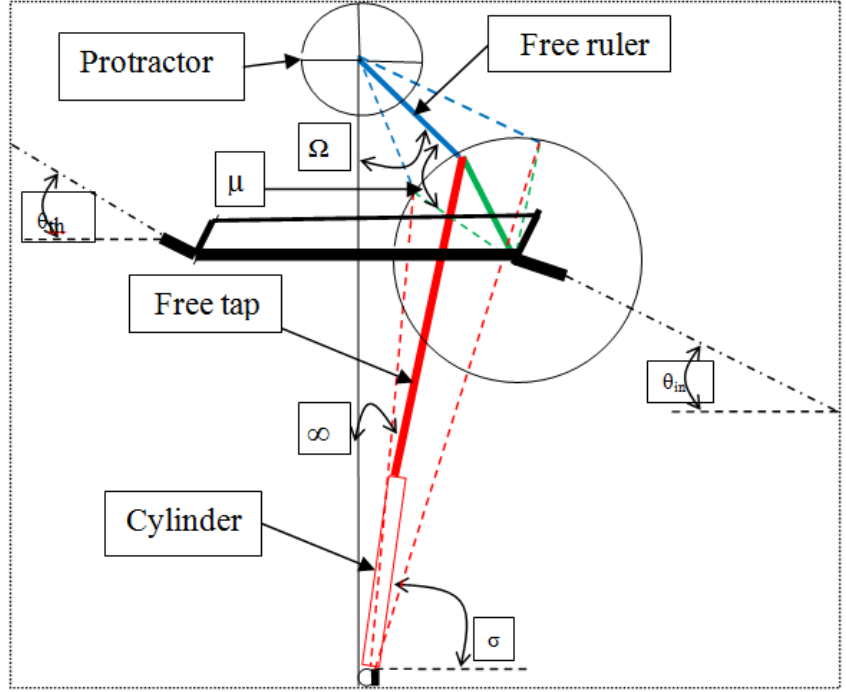

Figure (4): The steering angles mechanism

By increasing $\left(\mathrm{L}_{\mathrm{ef}}\right)$ from 2.0 to $9.8 \mathrm{~cm}$ the $\left(\theta_{\mathrm{ac}}{ }^{\circ}\right)$ increasing from [11.0 to $\left.38.8^{\circ}\right]$; from [11.0 to $37.8^{\circ}$; ; from [11.0 to $36.94^{\circ}$ ] and from [11.0 to $\left.35.5^{\circ}\right]$ at $(1 / b)$ of $0.43 ; 0.522 ; 0.6$ and 0.7 respectively. Increasing the cylinder length $\left(\mathrm{Lef}_{\mathrm{ef}}\right)$ directly increases the theoretical outer steering angles 
$\left(\theta_{\mathrm{th}}{ }^{\circ}\right)$ at different ratio of $(1 / \mathrm{b})$ and vice versa at increasing the $(1 / \mathrm{b})$ ratio. For example, at the cylinder length $\left(\mathrm{L}_{\mathrm{ef}}\right)$ equal to $4.6 \mathrm{~cm}$ the theoretical outer steering angles $\left(\theta_{\mathrm{th}^{\circ}}\right)$ adapted $19.3 ; 18.2 ; 17.3$ and $16.2^{\circ}$ for $(1 / \mathrm{b})$ $0.43 ; 0.52 ; 0.60$ and 0.7 respectively.

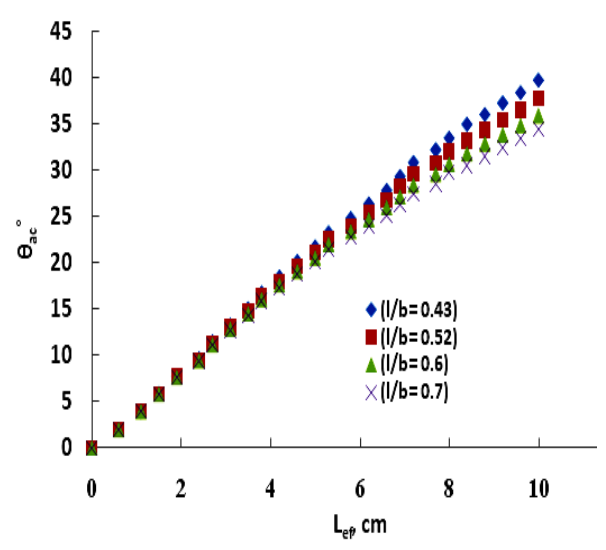

Figure (5): Response surface plot between $\mathrm{L}_{\mathrm{ef}}$ and $\theta_{\mathrm{ac}}{ }^{\circ}$ at different $\mathrm{l} / \mathrm{b}$

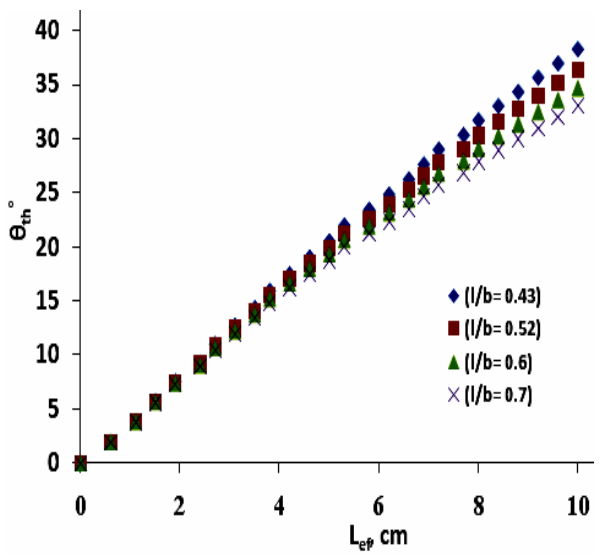

Figure (6): Response surface plot between $\mathrm{L}_{\mathrm{ef}}$ and $\theta_{\mathrm{th}}{ }^{\circ}$ at different $\mathrm{l} / \mathrm{b}$

The estimated regression equations for the above relations were found as:

$$
\begin{aligned}
& \theta_{\mathrm{ac}}{ }^{\circ}=8.88+3.56\left(\mathrm{~L}_{\mathrm{ef}}\right)-11.4(1 / \mathrm{b}) \\
& \theta_{\mathrm{th}}{ }^{\circ}=8.39+3.42\left(\mathrm{~L}_{\mathrm{ef}}\right)-11.3(\mathrm{l} / \mathrm{b})
\end{aligned}
$$

The value of the coefficient of determination (R-Sq) was found as $99.1 \%$ and $98.7 \%$ at levels of 0.05 percent for actual and theoretical steering angles respectively. It means that the proportion of variation in the response data was very close.

\section{Steering wheel angle via actual and theoretical steering angles}

The effect of the steering wheel angles $\left(S_{w a}\right)$ on each of actual $\left(\theta_{a c}{ }^{\circ}\right)$ and theoretical $\left(\theta_{\mathrm{th}}{ }^{\circ}\right)$ outer steering angles were illustrated in figures (7) and (8) at different ratio of $(1 / b)$. Generally, increasing the steering wheel angles $\left(S_{\mathrm{wa}}\right)$ directly increases the $\left(\theta_{\mathrm{ac}}\right)$ and $\left(\theta_{\mathrm{th}}{ }^{\circ}\right)$ of steering angles at different ratio of $(1 / b)$. On the other side, the ratio of $(1 / b)$ for the changing range under the experimental studies was effective. For example, at the steering wheel angles $\left(S_{\mathrm{wa}}\right)$ equal to $4.2 \mathrm{rad}$ the $\left(\theta_{\mathrm{ac}}\right)$ becomes $20.6 ; 19.6$; 18.7 and $17.7^{\circ}$ and $\left(\theta_{\mathrm{th}}{ }^{\circ}\right)$ becomes $19.4 ; 18.4 ; 17.5$ and $16.41^{\circ}$ for $(1 / b)$ ratio of $0.43 ; 0.52 ; 0.60$ and 0.7 respectively. 

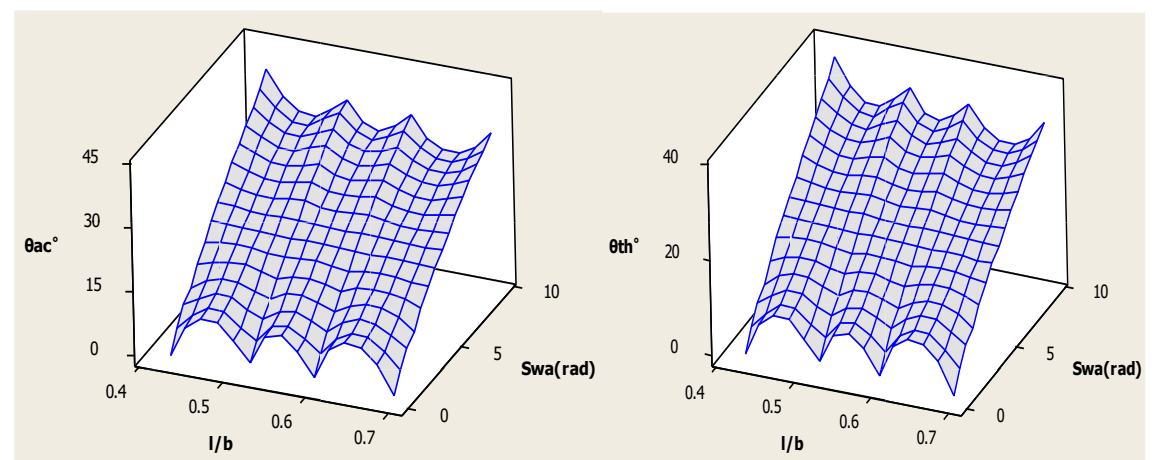

Figure (7): Response surface plot between Figure (8): Response surface plot between $\theta_{\mathrm{ac}}{ }^{\circ}$ and $\mathrm{S}_{\mathrm{wa}}$ at different $\mathrm{l} / \mathrm{b}$ $\theta_{\mathrm{th}}{ }^{\circ}$ and $\mathrm{S}_{\mathrm{wa}}$ at different $\mathrm{l} / \mathrm{b}$

For steering wheel data, the regression equations are estimated to be:

$$
\begin{aligned}
& \theta_{\mathrm{ac}}{ }^{\circ}=10.1+3.63\left(\mathrm{~S}_{\mathrm{wa}}, \mathrm{rad}\right)-11.1(\mathrm{l} / \mathrm{b}) \\
& \theta_{\mathrm{th}}{ }^{\circ}=9.51+3.49\left(\mathrm{~S}_{\mathrm{wa}}, \mathrm{rad}\right)-11.1(1 / \mathrm{b})
\end{aligned}
$$

The values of the coefficient of determination (R-Sq) were found as $98.7 \%$ and $99.1 \%$ at levels of $0.05 \%$ for $\left(\theta_{\mathrm{ac}}{ }^{\circ}\right)$ and $\left(\theta_{\mathrm{th}}{ }^{\circ}\right)$ respectively. Referring to Eq. 3 and 4, it easy to notes that, the effect of " $1 / \mathrm{d}$ " ratio on each of $\left(\theta_{\mathrm{ac}}{ }^{\circ}\right)$ and $\left(\theta_{\mathrm{th}}{ }^{\circ}\right)$ was found constant.

\section{Turning radius and times}

The effect of the steering wheel angles $\left(S_{w a}\right)$ on turning radius (R) was illustrated in figure (9) at different ratio of (1/b). Generally, increasing the steering wheel angles $\left(S_{\mathrm{wa}}\right)$ directly decreases the turning radius $(\mathrm{R})$ at different ratio of $(1 / b)$. On the other side, the ratio of $(1 / b)$ for the changing range under the experimental studies was effective. For example, at steering wheel angles $2.4 \mathrm{rad}$, turning radius becomes:-

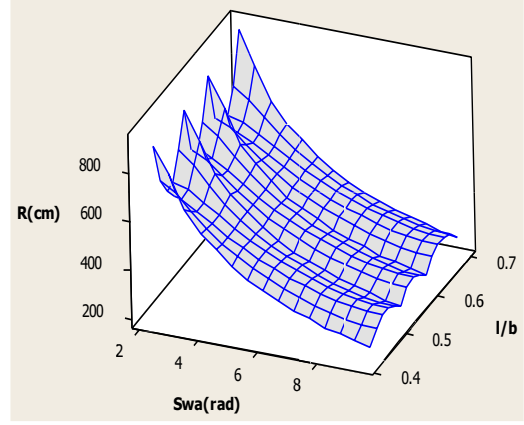

Figure (9): Response surface plot between $\mathrm{R}$ and $\mathrm{S}_{\mathrm{wa}}$ at different $\mathrm{l} / \mathrm{b}$
$519 ; 484 ; 442$ and $434 \mathrm{~cm}$ for $(1 / \mathrm{b})$ $0.43 ; \quad 0.52 ; \quad 0.60$ and 0.7 respectively. For the steering wheel data, the regression equation is estimated to be:

$\mathrm{R}=786-71.2\left(\mathrm{~S}_{\mathrm{wa}}, \mathrm{rad}\right)+75.7 \mathrm{l} / \mathrm{b}$ The value of the coefficient of determination (R-Sq) was found as $87.2 \%$. It means that the proportion of variation in response data was close. 
Practically, the average of turning radius for the hydraulic steering system was permanent as $2.5 \mathrm{~m}$ against $3.0 \mathrm{~m}$ for mechanical steering. The total turning times decreases by increasing the tractor speeds for both of mechanical and hydraulic steering but the rate of decreasing for hydraulic is lower that for mechanical (Table-1). In addition, the values of the total of turning time were $(240,210$ and 195sec) and (450, 420 and 390sec) for the hydraulic and mechanical steering system respectively at average tractor speed of $(4.0 ; 5.5$ and $7.0 \mathrm{~km} / \mathrm{h})$ and $(1 / \mathrm{b})$ ratio of 0.522 .

Table (1): The total turning times for hydraulic and mechanical steering

\begin{tabular}{|c|c|c|c|c|c|c|}
\hline \multirow{3}{*}{ Measurements, s } & \multicolumn{3}{|c|}{ Hydraulic steering system } & \multicolumn{3}{|c|}{ Mechanical steering system } \\
\hline & \multicolumn{6}{|c|}{ Forward speed, km/h } \\
\hline & 4.0 & 5.5 & 7.0 & 4.0 & 5.5 & 7.0 \\
\hline Turning time per one, $\mathrm{s}$ & 8.0 & 7.0 & 6.5 & 15.0 & 14.0 & 13.0 \\
\hline Total turning time & 240 & 210 & 195 & 450 & 420 & 390 \\
\hline
\end{tabular}

\section{Field capacity and efficiency}

The relationship between tractor speed and each of field capacity and efficiency was tabulated in table (2) for hydraulic and mechanical steering systems and constant tractor ratio of $(1 / \mathrm{b}=0.522)$. The actual operating times for the hydraulic and mechanical steering systems were $(0.5,0.41$ and $0.34 \mathrm{~h} / \mathrm{fed})$ and $(0.56,0.45$ and $0.39 \mathrm{~h} / \mathrm{fed})$ at tractor speeds of [4.0, 5.5 and $7.0 \mathrm{~km} / \mathrm{h}$ ] respectively. Generally, the increasing of actual time for mechanical steering system was higher than that for the hydraulic steering system.

Subsequently, the actual field capacities for hydraulic and mechanical steering systems were (2.0, 2.44 and $2.94 \mathrm{fed} / \mathrm{h})$ and (1.78, 2.22 and 2.56 $\mathrm{fed} / \mathrm{h}$ ) at tractor speed of [4.0, 5.5 and $7.0 \mathrm{~km} / \mathrm{h}]$ respectively. Generally, the rate of field capacity increasing for hydraulic relative to mechanical steering system were $1.13 ; 1.1$ and 1.15 time at tractor speed of [4.0, 5.5 and 7.0 $\mathrm{km} / \mathrm{h}$ ] respectively. 
Commonly, the field capacity increases with increasing of tractor speeds and vice versa for field efficiency. The highest value of field efficiency was $80 \%$ at forward speed of $4 \mathrm{~km} / \mathrm{h}$ for hydraulic steering system, as well as, the lowest value (64\%) was recorded at $7 \mathrm{~km} / \mathrm{h}$ for mechanical steering system. So, the best field efficiency was at $V_{1}=4 \mathrm{~km} / \mathrm{h}$ for hydraulic and mechanical steering system.

Table (2): Field capacity and efficiency at $(1 / \mathrm{b}=0.522)$ constant.

\begin{tabular}{|c|c|c|c|c|c|c|}
\hline \multirow[t]{3}{*}{ Measurements } & \multicolumn{3}{|c|}{$\begin{array}{c}\text { Hydraulic steering } \\
\text { system }\end{array}$} & \multicolumn{3}{|c|}{$\begin{array}{c}\text { Mechanical steering } \\
\text { system }\end{array}$} \\
\hline & \multicolumn{6}{|c|}{ Forward speed, km/h } \\
\hline & 4.0 & 5.5 & 7.0 & 4.0 & 5.5 & 7.0 \\
\hline Theoretical time (h/fed) & 0.40 & 0.32 & 0.25 & 0.40 & 0.32 & 0.25 \\
\hline Theoretical field capacity (fed/h) & 2.50 & 3.16 & 4.00 & 2.50 & 3.16 & 4.00 \\
\hline Actual time (h/fed) & 0.50 & 0.41 & 0.34 & 0.56 & 0.45 & 0.39 \\
\hline Actual field capacity (fed/h) & 2.00 & 2.44 & 2.94 & 1.78 & 2.22 & 2.56 \\
\hline Field efficiency (\%) & 80.00 & 77.20 & 73.50 & 71.20 & 70.25 & 64.00 \\
\hline
\end{tabular}

\section{Fuel consumption}

From table (3) the fuel consumption for each of hydraulic and mechanical steering systems were calculated. Generally, tractor fuel consumption (literlh) increases with increasing tractor speeds for each of hydraulic and mechanical steering and vice versa for specific fuel consumption (literlfed). This results compatible with Sahu and Raheman (2008), Xue-Ping et al. (2009), Dwight et al. (2010) and Michihisa et al. (2011). The rate of increasing fuel consumption (literlh) was 1.286 and 1.276 times for hydraulic and mechanical steering respectively. But the rate of decreasing for (literlfed) was 0.876 and 0.887 times for the same of above conditions. 
Table (3): Fuel consumption at $(1 / \mathrm{b}=0.522)$ constant

\begin{tabular}{|c|c|c|c|c|c|c|}
\hline \multirow[t]{3}{*}{ Measurements } & \multicolumn{3}{|c|}{ Hydraulic steering system } & \multicolumn{3}{|c|}{$\begin{array}{c}\text { Mechanical steering } \\
\text { system }\end{array}$} \\
\hline & \multicolumn{6}{|c|}{ Forward speed, km/h } \\
\hline & 4.0 & 5.5 & 7.0 & 4.0 & 5.5 & 7.0 \\
\hline Fuel consumption (liter/h) & 6.8 & 7.8 & 8.75 & 6.45 & 7.35 & 8.23 \\
\hline Specific fuel consumption (liter/fed) & 3.4 & 3.2 & 2.98 & 3.62 & 3.31 & 3.21 \\
\hline
\end{tabular}

\section{REFERENCES}

Cheng, Y. and N. Bradley (2007). Response Surface Methodology. M. Sc. Thesis, Indiana University of South Bend.

Dwight, R. E.; V. I. Adamchuk; M. F. Kocher and R. M. Hoy (2010). Using a vision sensor system for performance testing of satellitebased tractor auto-guidance. Computers and Electronics in Agriculture, 72 (2): 107-118.

El- Awady, M. N.; A. M. M. Sarhan and H. S. Al-Katary (2009). A study on agricultural tractors steering mechanism (1- the steering angles). Misr J. Ag. Eng., 26 (4): 1725 - 1742.

Habibi, H.; K. H. Shirazi and M. Shishesaz (2008). Roll steer minimization of McPherson-strut suspension system using genetic algorithm method. Mech. Mach. Theory, Vol. 43, pp. 57-67.

Hanzaki, A. R.; P. V. M. Rao and S. K. Saha (2009). Kinematic and sensitivity analysis and optimization of planar rack-and-pinion steering linkages. Mech. Mach. Theory, Vol. 44, pp. 42-56.

Hoyle, J. B. (2007). Bump steer effects in a 10 ton truck with a leafspring suspension, Proc. Inst. Mech. Eng., Part D: J. Automot. Eng., Vol. 221, pp. 1051-1069.

Ismail, Z. E.; M. Ibrahim.; A. F. Bahnas and I. El-Sebaee (2012). Steering evaluation of tractor using the response surface methodology. Misr J. Ag. Eng., 19 (4): 493 - 510. 
Michihisa, I.; N. Hiroshi; T. Hiroki; O. Toho and N. Taku (2011). Small-radius turning performance of an articulated vehicle by direct yaw moment control. Computers and Electronics in Agriculture, Vol. 76, pp. 277-283.

Montgomery, D. C. (2005). Design and analysis of experiments: Response surface method and designs. New Jersey: John Wiley and Sons, Inc.

Sahu, R.K. and H. Raheman (2008). A decision support system on matching and field performance prediction of tractor-implement system. Computers and Electronics in Agriculture. 60 (1): 76-86.

Watanabe, K.; J. Yamakawa; M. Tanaka and T. Sasaki (2007). Turning characteristics of multi-axle vehicles. J. Terramecha., Vol. 44, pp. 81-87.

Zhao, X. P.; L. Xin; C. Jie and M. J. Lai (2009). Parametric design and application of steering characteristic curve in control for electric power steering. Mechatronics.19 (6): 905-911.

$$
\begin{aligned}
& \text { الملخص العربيى } \\
& \text { الحكم على تأثثير طول ذراع المكبس وزوايا طارة التوجيه } \\
& \text { على الجرار المعدل هيدروليكيا }
\end{aligned}
$$

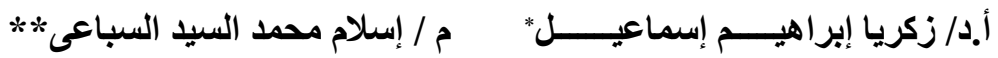

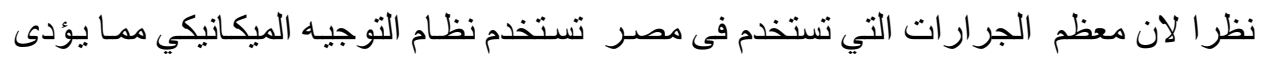

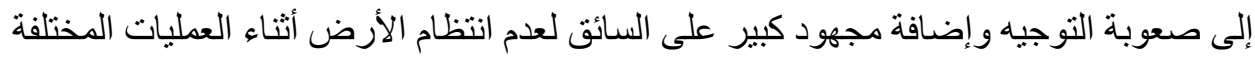

$$
\begin{aligned}
& \text { للزر اعة والحصـاد و النقل. تحت الدر اسـة تم استخدام جرار زر اعي موديل (IMT) قدرتـه هـ } \\
& \text { حصان وتحولية ليصبح نظام التوجيه هيدروليكي. } \\
& \text { * أستاذ تكنولوجيا القوي والآلات ـ الهندسة الزراعة - جامعة المنصورة. } \\
& \text { ** باحث مساعد - معهد بحوث الهندسة الزراعية ـ مركز البحوث الزراعية ـ جيزة. }
\end{aligned}
$$


من خلال التجارب تم التوصل إلى تقليل نصف قطر الدوران للجر ار ذو التوجيه الهيدروليكي

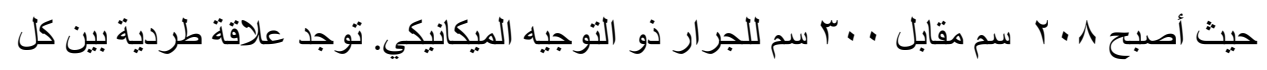

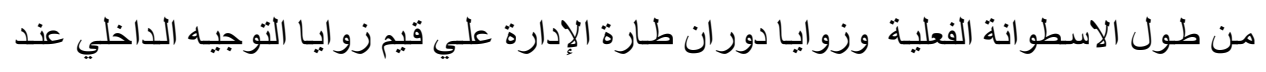
نسب (1/b) المختلفة.

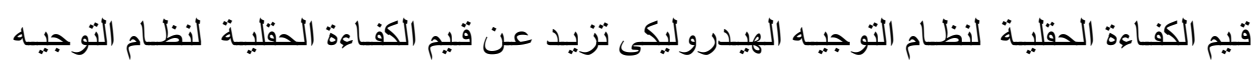

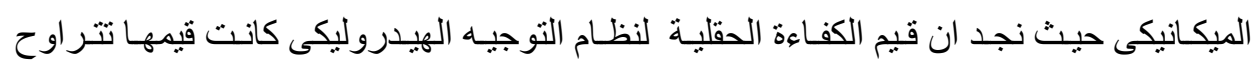

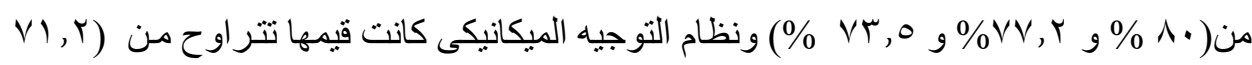

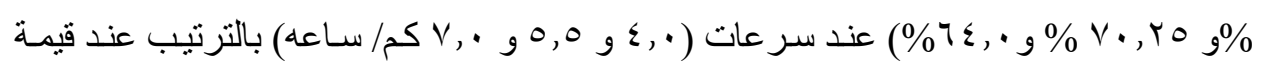

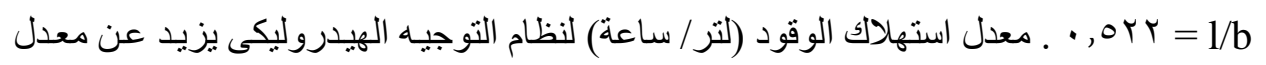

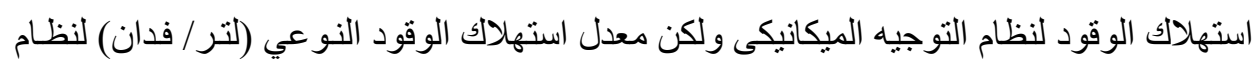
التوجيه الهيدروليكى يقل عن معدل استهلاك الوقود لنظام التوجيه الميكانيكانيكيك. 